\title{
Managing Organisational Ethics: Professionalism, Duty and HR Practitioners
}

\author{
Michael Segon \\ RMIT University, Australia
}

\begin{abstract}
After almost 20 years of researching, teaching and consulting in business and organisational ethics, this emerging field seems to be facing an organisational dilemma. Who should manage the ethics and integrity systems that are slowly being adopted by Australian firms?

During consulting engagements with numerous Australian businesses it has become clear that the task of managing ethics and integrity systems, i.e. creation of codes of ethics, ethics committees, information programs, conducting of audits, etc, more often than not seems to be delegated to Human Resources Managers and their Departments. This trend appears to be unique to the Australian setting and contrary to the US where Ethics Officers and Compliance Officers assume this role.
\end{abstract}

The purpose of this paper is to consider the question of who is appropriate to manage the ethics function in the Australian context. A literature review will examine the concept of professionalism and what characteristics and duties qualifies an occupation as a profession. In particular it will identify the role of knowledge and the existence of an organisation or association that regulates and licences the individual to operate as a professional. It will then identify the roles, responsibilities and characteristics of ethics officers so as to determine the knowledge required to undertake this task in an organisation setting.

Given the predisposition to delegate this function to Human Resources practitioners in Australian Organisations, a review of formal Postgraduate Human Resources programs at the major Australian Universities will be undertaken. The objective of this task is to determine whether such programs contain any specific ethics content, in particular the creation of codes of ethics, codes of conduct, ethics training and the conducting of ethics audits. This will establish whether Australian Human Resource professions are sufficiently equipped with the knowledge and capabilities required to undertake this function through their formal education.

\section{Keywords}

Ethics, integrity, professionalism, Human Resources Managers

\section{Introduction}

Historically the term profession was applied to specific vocations such as medicine, law and engineering. What was characteristic of these professions was a high degree of expert knowledge attained over a significant period of time, high standards of practice and an association that restricted access and provided the licence to operate (May 1989). However, many vocations and crafts are now laying claim to the term "profession" including sports men and women, administrators, cleaners, etc,. Koehn (1994) suggests that term has been applied indiscriminately to anyone who exhibits a high level

Copyright (C) 2010 Victoria University. This document has been published as part of the Journal of Business Systems, Governance and Ethics in both online and print formats. Educational and non-profit institutions are granted a nonexclusive licence to utilise this document in whole or in part for personal or classroom use without fee, provided that correct attribution and citation are made and this copyright statement is reproduced. Any other usage is prohibited without the express permission of the publisher. of style, skill or even cunning. However a review of literature relevant to professions and professionalism, suggests that many of these "occupations that lay claim to being professions, do not satisfy the conditions or posses the characteristics required to be classified as traditional professions. This raises the prospect of individuals who claim to be professionals but lack the expert knowledge typically associated with 
a profession, are acting outside their expertise and therefore violating the professional a duty to act within the limits of their knowledge.

One such area that seems to typify this trend is the Human Resource Manager/specialist and the management of ethics polices and culture within Australian organisations. The author's consulting experience has identified that in many Australian organisations, in both public and private sectors, the ethics function is either delegated or claimed by human resource management practitioners (Segon, 2004). The emergence of the ethics officer function in the United States has resulted in clear roles, responsibilities and importantly an identification of the type of knowledge required to assume such positions (Collins, 2009; Adobor, 2006; Llopis, Reyes-Gonzales and Gasco, 2007; Izraeli and BarNir, 1998 and McNamee, 1991). As expert knowledge is one of the characteristics required of professionals a key question is whether Human Resource practitioners, who claim to be professionals, have the required expert knowledge to carry out this function? This paper will consider the concept of professionalism and the requirements to be considered a professional. It will examine the roles, duties and knowledge required of ethics officers and compare this to knowledge currently addressed in Human Resource Management postgraduate programs in Australian Universities that have been accredited by the Australian Human Resource Institute, being the association that represents the interest of human resource practitioners.

\section{Professionalism}

Koehn (1994) states that the notion of a professional is essentially a normative one because who qualifies as a professional varies according to the norms or standards of behaviour that the professional is bound to obey. However she does summarise the basic characteristics of a professional to be trustworthy agent of clients either because they are experts or they are service providers who will obey a client's will for a fee. May (1989) states that Abraham Flexner's 1910 Carnegie report on medical education attempted to deliberately define the essence of a profession that has become the basis for identifying and legitimising other groups of workers as professionals.

\section{Characteristics of Professionals}

Watkins (1999) puts forward a view that the professions can be differentiated from other groups in society because of specific characteristics of its members including: the possession of specialised skills, the attainment of expert knowledge which is usually based on mastery acquired through intellectual and practical training and the existence of professional body or association that is charged with the maintenance of the profession and to ensure that members abide by appropriate standards.

According to Flexner (1910) to qualify as a profession an occupation had to satisfy six criteria:

1. Possess and draw upon a store of knowledge that was more ordinary than complex

2. Secure a theoretical grasp of the phenomenon with which it dealt

3. Apply its theoretical and complex knowledge to the practical solution of human and social problems

4. Strive to add and improve its stock of knowledge

5. Pass on what it knew to novice generations not in a haphazard fashion but deliberately and formally

6. Establish criteria of admission, legitimate practice and proper conduct and

7. Be imbued with altruistic spirit

May (1989) suggests that Flexner's original characteristics of professionals can be synthesized to three being an intellectual component, a moral component and an organisational component. De George (1999) and Ardaugh (2010) describe similar characteristics including the possession of expert knowledge, restriction of entry to the field of practice and management of the field by some form of association and a requirement of service to the public. 


\section{The Intellectual Component: Knowledge and Power}

According to Gold, Rodgers, and Smith (2002) a major aspect of professionalism is the power derived from expert knowledge and skill and the ignorance or absence of such knowledge and skill on the part of the client. They further add that the client accessing this information cannot bridge the deficiency in knowledge, rather it has to be transformed into knowledge through considered application within a given context. Eraut (2000) provides a similar position on the nature of the expertness suggesting that the client is dependent on the professional because they are unable to address their problem by procedural knowledge alone or by following a manual. This is similar to Freidson (1970) classification of professional knowledge as "pure" knowledge that is largely theory and typically limited to codified science and a form of practical knowledge that guides the professional's application of the knowledge to the problems faced by society or the client.

Mangham and Pye (1991) and Cheetham and Chivers (2000) draw further distinctions between the two types of professional knowledge suggesting a category of "scientific knowledge" that includes logic, analysis and the ability to engage in rational deduction, and "behavioural knowledge" which they describe as including the tacit and intuitive understanding that are necessary for engagement. Gold, Rodgers, and Smith (2002) identify two distinct types of knowledge that typify professionals. The first is what, Eraut (2000) calls public or propositional knowledge that is usually acquired through formal learning which is also linked to professional accreditation. According to Abbott (1988), it is the abstract nature of this knowledge that distinguishes the professional from other individuals and groups because of their ability to apply this abstraction to problems, redefining them and the possession of what is required to solve them. Mangham and Pye (1991) argue that effective professional practice requires a combination of the two forms of knowledge and that whilst they are difficult to separate, each plays the role of informing the other at the point of action. Oakeshott (1962) provides a similar categorisation of "technical knowledge", which is capable of being articulated and codified and "practical knowledge", which is typically not easily codified.

This is consistent with May (1989) who suggests that a professional draws on a complex and esoteric body of knowledge that in not available or acquired by everybody. He further states that a characteristic of this knowledge is that it extends beyond mere training to education and development. He proposes that for this reason Flexner (1910) maintains that the professional education should be based in a university setting to distinguish it from apprenticeship systems and the crafts. Furthermore he states that a function of the professional is to continue to contribute to the body of knowledge through further research, however he does state that not all professionals need to be researchers but that the profession must lay the foundation for the advancement and progress in the field, typically at a University. Lusch and O'Brien (1997) suggest that a profession "is an occupation that requires extensive formal education and often formal requirements. Cogan (1953, p.33) defines it as "a vocation whose practice is founded upon an understanding of the theoretical structure of some department of learning or science, and upon the abilities accompanying such understanding". Wall (1998) and Winch (2004) similarly state that professionals are characterized by the possession of, particular kinds of knowledge, which are abstract and practical, massive in extent, difficult to master over a long period of time.

These distinctions also parallel May (1996) assertion that professionalism is made up of two significant attributes being conceptual knowledge associated with expertise (mastery) and behaviour standards, which apply within the workplace and society. This categorization is consistent with the input competency model of management development as advocated by McClelland (1973), Boyatzis (1982), Pedlar, Burgoyne and Boydell (2001); Hellriegel et al. (2007), Whetten and Cameron (2007) and the emotional intelligence model as described by Goleman, Boyatzis and McKee (2004) that suggests that the path to mastery is based on the development of competence that is made up of three components: conceptual knowledge: this represents the body of knowledge that underpins or explains concepts and processes which individuals must acquire in order to understand what is happening or what they need to do. It informs practice and is a key to being able to adapt to different context and to deal with different people, however it does not by itself mean they will become better managers. The second component is behavioural knowledge which are the actual behaviours or skills that individuals need to develop, often referred to as helping skills such as communication skills including active 
listening, questioning skills, paraphrasing, assertiveness etc. Whilst the development of such skills is critical, without the conceptual knowledge of how they work and why and in what context they should be used, managers may be unable to adapt and change their behaviour to suit different contexts. The this and final component is attitudes, which as Segon and Booth (2010) alternatively describe as genuineness, that relates the way in which individuals interact with others and demonstrate our conceptual and behavioural skills.

\section{Professional Duty and the Limits to Practice}

Koehn (1994), Sager (1995), May (1996) and Warren (1995) suggest that true professions are bound by a duty to act within the limits of their knowledge. Does this then suggest that professions are also bound by a professional duty only engage in practices and provide advice to clients that is within their knowledge limits? If so then to do otherwise would be a violation of professional duty.

Beauchamp and Bowie (1997) state that professional practice standards hold that obligations and other standards of moral conduct are determined by the customary practice of the professional community. They suggest that proponents of such as positions argue that individuals are charged with various responsibilities or duties, for example, avoiding harm, honouring warranties avoiding conflicts of interest and obeying legal requirement. They also highlight that such individuals must use professional criteria for determining appropriate actions. They specifically state that any person with out expert knowledge is unqualified to determine what needs to be done. This suggests that professions have a duty to act within the limits of their expert knowledge. Whilst it does not imply that such knowledge cannot be extended, in fact Flexner (1910) May (1996) and others acknowledge that professionals are expected to advance their knowledge, it is also consist with the concept of the organisation of the profession that such additional knowledge needs to be acknowledged or accredited before it should be used. Bowie (1990) provides further guidance on the use of expert knowledge stating that the chief function of a professional is not to use their specialist knowledge to maximise income, rather it is to use it to protect ignorant clients from being exploited by others.

\section{Who should Responsible for Organisational Ethics?}

According to Trevino and Nelson $(1999,2006)$ ethics is an integral part of the organisation's overall culture. Designing an ethical organisation means systematically analysing all aspects of the organisation's culture and aligning them so that they support ethical behaviour and discourage unethical behaviour. Preston (1994) the creation and adoption of an ethical system within an organisation, which can also be termed the institutionalisation of ethics, should be seen as a multifaceted approach that 'main-streams' concerns about the ethical issues facing organisations. Sampford (1994) also outlined a general strategy for the institutionalisation of ethics specific to the public sector, the principles of which are equally applicable to other industries and organisations. Many other ethical theorists such as Hoffman (1995), Kitson and Campbell (1996), Ritchie (1996); Ferrell and Fraedrich and Ferrell (2006), Lagan (2005) and Trevino and Nelson (1999, 2006) have developed similar guidelines which essentially detail the components of an organisational ethical framework. Hoffman, Driscoll and Painter-Morland (2001) identified that the ethics initiative could be deemed to start with senior managers making an explicit commitment to long-term success. They stress that the executive level of an organisation needs to assume responsibility for ethics and ensuring appropriate resources and clear responsibility be established. They argued that ethics must be managed like any other internal function. Just as the financial integrity of an organisation is established through the appointment of financial officers, and, with larger organisations, finance sections and divisions, so too must the ethical system be characterised by a structured approach that would increase in importance as organisational size increases.

Buchholz (1989) attributed major problems with codes to the difficulty of determining who in the organisation should have the power and authority for enforcement, the difficulty of getting information about violations, and the problems of uniform and impartial enforcement. Ferrell and Fraedrich (1997) maintained the importance of having a manager in charge of the ethics programme to insure implementation. Many American Fortune 1000 firms have recognised this importance through the appointment of ethics officers. The obvious advantage is the dedication of an organisational 
structure to ethical management. Ferrell and Fraedrich (1997) also highlighted the importance of a high level manager responsible for coordinating, developing, revising and ensuring compliance with the programme. The involvement and support of high-level management is mandatory as is ownership and involvement by lower level staff (Connock et. al. 1995).

\section{Ethics Officers As Managers of Organisational Ethics}

Collins (2009) states that legislative requirements in the US provide a judicial incentive for assigning a high level employee the responsibility of managing ethical performance. Many organisations in the US have created the position of ethics compliance officer that allows sensitive information to be shared without being diluted by the chain of command. Llopis, Reyes Gonzales and Gasco (2007) state that an ethics officer can be simply described as the manager whose main responsibility is achieving the appropriate standards or codes of ethics in an organisation. More precisely the ethics officer is someone who makes sure the firm is doing its best to satisfy internal and external stakeholders. Hoffman (1995) states that the role of an ethics officer is to oversee the corporate ethics program and help steers the company around ethical pitfalls. Driscoll and Hoffman (2000) suggest that whilst ethical responsibility should be assumed by all members of the organisation, the coordination and management of the system designed to establish, inform and maintain those standards cannot be left to each individual but rather needs to be seen as a function within the organisation as with other business functions such as auditing, human resources, marketing etc.

\section{Expert Knowledge required by Ethics Officers}

Collins (2009) identifies that the appointment of an ethics compliance officer, or in effect the manager of the ethics framework must be based on expertise and an understanding of the organisation. Adobor (2006) states that the ethics officer role is unique in organisation in that it faces multiple and competing expectations from internal and external organisational stakeholders. This is consistent with Llopis, Reyes-Gonzales, and Gasco (2007) who suggest that the essential requirement of an ethics officer can be summarised as having a wider knowledge of the firm, mastering management techniques as well as theoretical and practical issues related to business ethics as with other senior executives having hierarchical authority or legitimate power to exert influence within the organisation. Izraeli and BarNir (1998) state that ethics officer must be trained in moral awareness and ethics theories (McNamee, 1992) and experienced in resolving ethical dilemmas. Such conceptual understanding is necessary to enable identification of moral dilemmas, an analysis of consequences of decisions and the promotion of social responsibility through educational programs.

Collins (2009) provides a similar multi-skill or multi-duty role including that managing the internal reposting system, assessing areas of ethical risk, monitor adherence to code of ethics and or conduct, oversee the ethics communication strategy, develop and interpret ethical polices oversee training and development in ethics and collect and analyse data and report such to senior executives. Adobor (2006) states that ethics officers need specific knowledge related to the field of governance and ethics such as any legislative requires such as Sarbanes-Oxley in the US and by comparison equal employment opportunity legislation and Section 73 of the Australian federal criminal code which pertains to bribery of foreign officials. However he also highlight that in addition to this specific knowledge, another type of competence is required which is knowledge of the firm's business, products and industry characteristics which he refers to as business knowledge. He cites Spreitzer et al. (1997) who state that such knowledge is a key factor for executive success. Adobor (2006) maintains that ethics officers with such business knowledge will have a better understanding of the organisation, the information it holds and how to access it. He suggests that such knowledge should result in the ethics officer experiencing less task complexity, ambiguity and positive affect role performance.

This again seems to reinforce the concept that an ethics officer seems to require an understanding of professional ethics as part of their professional knowledge. 


\section{Ethics Officer Duties and Job Function}

Adobor (2006); Llopis, Reyes-Gonzales, and Gasco (2007); Izraeli and BarNir (1998) Trevino and Nelson (1999, 2006) Driscoll and Hoffman (2000) Hoffman, Driscoll and Painter-Morland (2001) all recognise the ethics officer function as involving specific roles and responsibilities as well as several characteristics that are necessary for effective role performance. Adobor (2006) highlights that individual role performance is to some extent based on the nature of the task and personal characteristics of the individual including their competencies and ability to deal with role conflict, ambiguity and influencing ability, Trevino (1986) suggests that ethics officers are supposed to be champions of ethical integrity and so their own moral integrity can be a key factor in performance.

Adobor (2006) highlights distinct categories of job function for ethics officers:

1. Ethics Education- this includes training design, training delivery and international program development.

2. Manage Compliance: this includes management of program documentation, direct handling of hotline or guideline and internal reporting. Assessing and reviewing vulnerabilities, i.e. ethics risk assessments establishing company policies and procedures and presentation and delivery of external presentations.

3. Adviser top management: this includes senior management and or board of director briefing and communications

4. Investigative oversight: this includes overseeing and conducting investigations of wrongdoing, and lastly

5. Corporate Social Responsibility, which includes communicate relation, corporate foundation/giving, shareholder relations, diversity issues and environmental compliance and human rights.

They state that each of these requirements is a necessary condition for an ethics officer to be effective, yet each one separately is not sufficient. Only all five characteristics will enable the EO to function at a sufficient level to promote the social responsibility of the firm. This seems to be consistent with Mangham and Pye (1991) concept that effective professional practice requires a combination of the forms of knowledge and that whilst they are difficult to separate, each plays the role of informing the other at the point of action.

Furthermore Collins (2009), Llopis, Reyes-Gonzales, and Gasco (2007) and Izraeli and BarNir (1998) highlight that ethics officer should ideally be a persona of senior authority with the trust of executive and the ability to influence decision-making but free from political pressure. Trevino and Nelson $(1999,2006)$ highlight that in many organisations functional structures often result in the ethics function being located within a specific departments such as audit or human resources that leads to a perception of a functional task rather than a holistic strategy relevant to the entre organisational culture. They argue that this is a major reason why the function should be independent and report directly to the CEO.

\section{Human Resources and the Ethics Function}

As identified in the introduction, anecdotal information and consulting experiences by the author suggest that in many Australian companies the organisational ethics function typically placed in the Human Resources department (Segon, 2004). The role of Human Resource practitioners within the context of organisational ethics has some attention over recent years. Winstanley, Woodall and Heery (1996) suggested that the HR function included a role of ethical stewardship that involved raising awareness about ethical issues, promoting ethical behaviour and in disseminating ethical leadership practices amongst leaders and managers. They also describe the as including communicating codes of ethical conduct, devising and providing ethics training to employees, managing compliance and monitoring arrangements, and taking a lead in enforcement proceedings. Woodd (1997) suggests that HR specialists need to be at the heart of policy design and implementation, to raise the issues and stimulate debate on ethics in the employment of people. In order to do so she suggests that will necessitate a degree of "expertise" in their field, emphasizing the need for continuing professional 
development. She further notes that this requirement for any profession and be shared by the associated institute. These descriptions appear consistent with characteristic of professional practice as described by May (1989) and Flexner (1910), De George (1999) and Ardaugh (2010) ad also some of the various roles of the ethics officer as described by Adobor (2006); Llopis, Reyes-Gonzales, and Gasco (2007); Izraeli and BarNir (1998) Trevino and Nelson (1999, 2006) Driscoll and Hoffman (2000) and Hoffman, Driscoll and Painter-Morland (2001).

A general hypothesis could be established that if human resource managers are to be responsible for organisational ethics, then they would posses relevant theoretical and complex knowledge related to ethics in addition to knowledge as skill concerning organisational issues and the specific issues facing their particular business or organisation. Furthermore this knowledge should therefore be an integral part of the formal education that individuals must acquire to move from novice to master in their professional field.

A simple method to determine this is to examine the range of formal education available to human resource practitioners to determine whether the appropriate expert content is covered. As the literature review highlighted the importance of senior positions holding the ethics officer function it is proposed that senior human resource positions are likely to be characterised by individuals holding postgraduate qualifications in human resource management. This is also consistent with the position advocated by May (1989) and Flexner (1910) that professional education should be based in a university setting and Lusch and O'Brien (1997) and Cogan (1953) that a profession involves extensive formal education and often formal requirements whose practice is founded upon an understanding of the theoretical structure.

\section{Review of Australian Human Resource Management Postgraduate Qualifications}

Based on the characteristic of a profession that an association of some type exists that licenses or accredits the professional, the appropriate body identified for the Australian context is the Australian Human Resources Institute (AHRI). The Institute "provides research, education and support to promote the standing of the profession and engender human resource management best practice within workplaces" It also specifically addresses the issue of human resource practitioners stating that it "also assists HR practitioners and people managers to excel in their profession through the provision of valued benefits and services that contribute to their workplace effectiveness and career development". The Institute also lists a series of strategic imperatives:

- Educate and lead HR practitioners and people managers to improve standards, practices and impact

- Be the career partner for HR practitioners and people managers

- Become the HR centre of excellence that organisations use to build their human resource management capability

- Provide relevant and accessible education, professional development and networking opportunities

- Provide services, tools and resources that contribute to professional effectiveness (http://www.ahri.com.au/scripts/cgiip.exe/WService=AHRILIVE/ccms.r?PageId=10920).

AHRI includes both institutional and individual membership and offers an accreditation service to formal education providers in addition to offering its own short courses, diploma and continuing educations programs to its members and to members of the public. These characteristics appear consistent with some of the characteristics of a profession as noted by May (1989); Flexner's (1910); De George (1999) and Ardaugh (2010) concerning the existence of an a association that provides and Eraut (2000) position concerning knowledge that is usually acquired through formal learning which is also linked to professional accreditation. The Institute's imperative to improve practices and impact and to further education is consistent with Flexner's position that the a function of the professional is to continue to contribute to the body of knowledge through further research, however he does state that not all professionals need to be researchers but that the profession must lay the foundation for the 
advancement and progress in the field. The fact that AHRI accredits formal educational programs would parallel Lusch and O'Brien (1997) suggestion that a profession is an occupation that requires extensive formal education and often formal registration or accreditation requirements. What is not consistent with the conditions of a profession put forward by Flexner (1910) is the requirements that the Institute or Association be the regulator of the profession and license or restrict access to the profession.

In order to determine whether Australian Human Resource managers are equipped to manage the organisational ethics function a review of the postgraduate human resource management programs accredited by AHRI was conducted. This involved accessing the program structure for the relevant masters degree to establish the content of the subject matter that all students undertaking the program were required to undertake. In other words only the compulsory core subjects were considered as electives or free subjects means that a comparison across the programs is not possible, as electives by definition would mean that individuals would not necessary select the same subjects and therefore would have divergent knowledge.

As at August 2010, the AHRI website lists 26 accredited Masters programs from 20 different Australian Universities. These programs ranged from specific Masters in Human Resource Management and Industrial Relations to Masters of Commerce and Masters of Business Administration with major concentrations in Human Resource Management and Industrial Relations. 19 Masters courses were examined based on the published structures listed on the University website linked from the AHRI accreditation web page. As previously identified only core or compulsory courses were identified with the exception being whether the individual program page identified any elective course in business or applied ethics. Given the variations in subject titles the author assumed that some subjects with like titles covered the same content, for example, subjects titled Strategic Human Resources and Human Resource Planning, were considered the same, subjects with strategic HR and HR Strategy were considered the same, and subjects dealing with Change, Consultancy or Transformation were identified as having the same content.

As can be seen from table 1 below, the majority of subjects across the 19 masters programs were largely related to human resource management or industrial relations content. The most common subjects across all programs were Human Resource Management, Strategic Human Resources and Performance management with generic Leadership, Management and Organisational Behaviour subjects also prominent. Only one Masters program identified an ethics related course as compulsory or a core subject being the Masters of Human Resource Management at Griffith University with a subject in Corporate Social Responsibility. Three Universities, University of Canberra, University of South Australia and University of Western Sydney, specifically identified business ethics or organisational ethics as a elective available to students undertaking their Masters programs. As this study was limited to published material it is not possible to deduce that the other Universities did not have business ethics electives available, however, Matten and Moon (2004) and Segon and Booth (2010) found that that only those students who elect to undertake these courses are exposed to concepts of business ethics etc. 
Table 1

University of Technology, Sydney Master of Business in H.R.M.

UTS, MBA in H.R.

Latrobe University

Post Grad Dip in H.R.M.

Charles Sturt University

Masters of H.R.M.

University of Sydney

Master of H.R and I.R

Curtin University

Master of H. R.

Monash University

Masters of HRM

Queensland University of Technology

Master of Commerce (H.R.M.)

University of Canberra, Master of H.R.M.

University of Melbourne

Masters of H.R.M.

University of South Australia.

Masters of H.R.M.

University of Western Sydney

Master of Commerce (H.R.M. and I.R.)

Deakin University

Master of H.R.M.

Griffith University

Master of H.R.M.

Murdoch University

Master of H.R.M.

Southern Cross University

Master of H.R. and Organisational

Development

Swinburne University

Master of Commerce (H.R.M.)

University of New England

Master of O.D. and H.R.M.

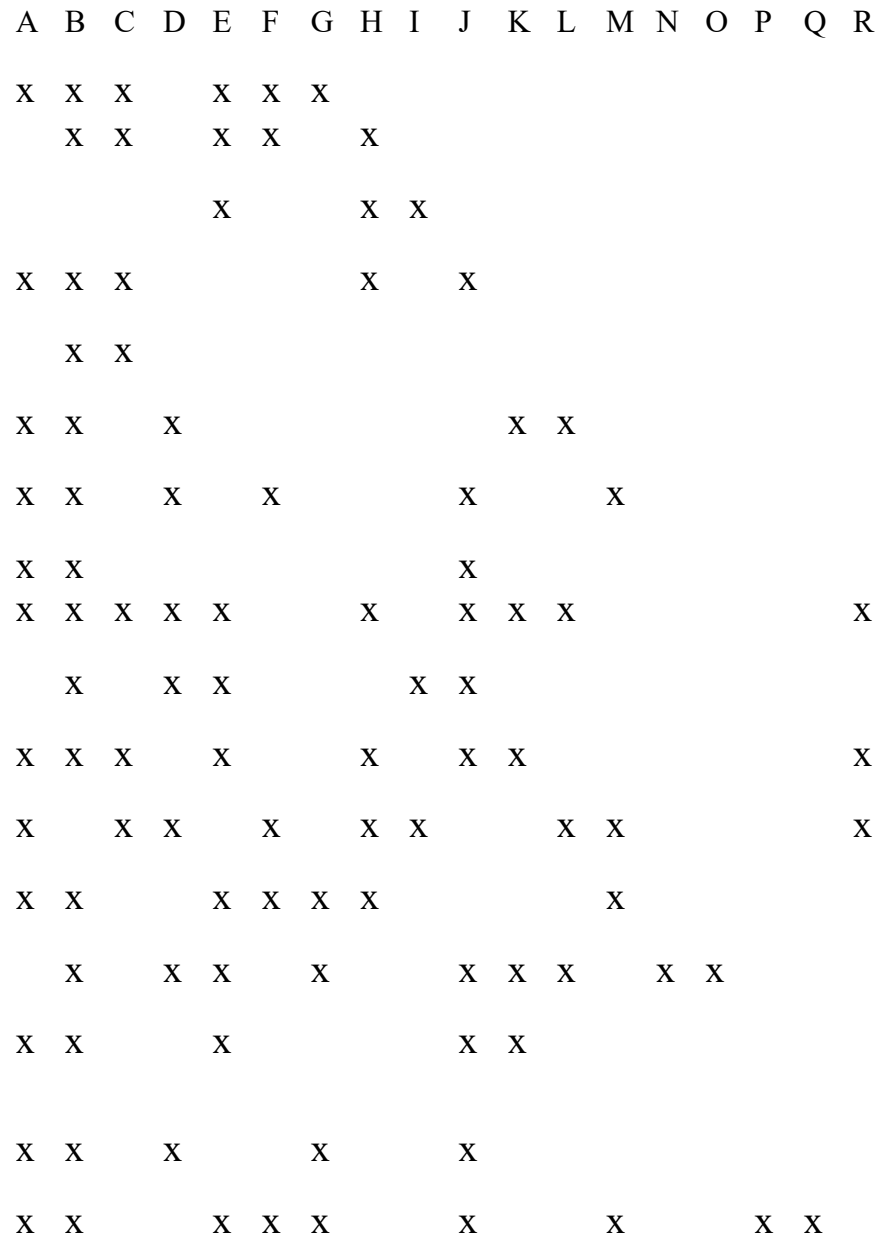

Legend

$\mathrm{A}=$ Subject called HRM

$\mathrm{B}=$ Subject called Strategic HRM

$\mathrm{C}=$ Subject called Industrial Relations

$\mathrm{D}=$ Subject called International or Global HR

$\mathrm{E}=$ Subject called Performance Management

$\mathrm{F}=$ Subject called Employment Relations

$\mathrm{G}=$ Subject called Organisational Development or Change Management

$\mathrm{H}=$ Subject called Industrial Law

I= Subject called Thesis or Research Project

$\mathrm{J}=$ Subject called Management, Leadership or Organisational Behaviour

$\mathrm{K}=$ Subject called Staffing

$\mathrm{L}=$ Subject called Remuneration

$\mathrm{M}=$ Subject called HR Issues

$\mathrm{N}=$ Subject called CSR

$\mathrm{O}=$ Subject called Training and Development and or Learning

$\mathrm{P}=$ Subject called Teams

$\mathrm{Q}=$ Subject called Business Context

$\mathrm{R}=$ Business Ethics Elective Subject

A comparison of the subjects would suggest that all of the Masters programs considered for this study, focus specifically on content matter related to human resource management, strategic human resources, industrial relations and general courses in management, leadership and organisational behaviour. Only one program, that offered by Griffith University, has a subject that could be seen as related to the field of organizational or business ethics, being Corporate Social Responsibility. Three other Universities, the University of Canberra, The University of South Australia and the University of Western Sydney identified specific subject in Business or Management Ethics as electives in their respective HR related masters programs. 
Arguably, the content of the 19 Masters programs could be seen as satisfying three of Flexner (1910) six criteria to qualify as a profession, (a) the possession of a store of knowledge that was more ordinary than complex, (b) securing a theoretical grasp of the phenomenon and (c) application of its theoretical and complex knowledge to the practical solution of human and social problems. Similarly the subjects would constitute Mangham and Pye (1991); Oakeshott (1962); Cheetham and Chivers (2000); Gold, Rodgers, and Smith (2002) Eraut (2000) and Freidson (1970) categorisation of two types of knowledge, and consistent with the concept of competency being conceptual and behavioural knowledge (McClelland, 1973; Boyatzis, 1982; Pedlar, Burgoyne and Boydell, 2001; Hellriegel 2002; Whetten and Cameron, 2007 and Goleman, Boyatzis and McKee (2004). However, this knowledge appears specific to the domain of human resource management and related disciplines such as industrial relations and law with some general management but not business ethics, organisational ethics or applied philosophy. Thus, if one were to use the definition of the types of knowledge required by professionals to engage in a particular field, the current graduates of these masters program would not acquire the necessary professional knowledge to create, administer or manage ethics programs due to the absence of any content related to the five functions of ethics officers and noted by Adobor (2006).

A further comparison to the roles and functions of ethics officer identified by Adobor (2006), Llopis, Reyes-Gonzales, and Gasco (2007), Izraeli and BarNir (1998), Trevino and Nelson (1999, 2006), Driscoll and Hoffman (2000) and Hoffman, Driscoll and Painter-Morland (2001) suggests that Human Resource managers do not possess the ethics education necessary for undertaking this role. Nor do they possess the expertise to conduct ethics risk assessment and compliance issues related to ethics, a function described by Harrison (2001). They would however possess the knowledge required to advise boards and senior management about specific issues related to strategic human resources and they also have a broad understanding of business issues through studies in leadership, management etc,. However the absence of specific study in ethics would suggest that they are not qualified or do they possess the specific expert knowledge identified by Izraeli and BarNir (1998) who state that ethics officers must be trained in moral awareness and ethics theories and experienced in resolving ethical dilemmas. Whilst Llopis, Reyes-Gonzales, and Gasco (2007) suggest that the essential requirement of an ethics officer can be summarised as a wider knowledge of the firm, which arguably these $M$ asters program may provide, including mastering management techniques, they do not address the specific theoretical and practical issues related to business ethics that Llopis, Reyes-Gonzales, and Gasco (2007) argue is required of ethics officers.

\section{Conclusion}

This paper has identified that professionalism is characterised by the possession of expert knowledge that is acquired over time that provides power over others who are unable to acquire, but require this knowledge as a means of finding practical solutions to problems. Furthermore it established that true professions are subject to numerous other conditions including the existence of an association that advances the interests of its members and accredits or licences them to practice thus restricting access to the profession. An $\mathrm{n}$ important ethical duty was also identified that professionals do not engage in activity outside their expertise. The role of etches officers was explained and the trend of human resource practitioners assuming this role in Australian organisations was highlighted. An examination of 19 Masters programs specialising in human resource management was conducted and it was established that virtual no ethics content was present in any of the compulsory aspects of these programs. As such it was concluded that Human Resource practitioners do acquire the required expert knowledge to manage and maintain organisational ethics and to do so would be a violation of their responsibilities if they were to be considered true professionals.

\section{References}

Abbott, A. 1988, The System of Professions An Essay on the Division of Expert Labor, University of Chicago Press, Chicago.

Adobor, H. 2006, "Exploring the Role Performance of Corporate Ethics Officers" Journal of Business Ethics, no. 69, p. 57-75. 
Ardaugh, D. 2010, Business as a Profession: A bridge too far or fair way to go? Lambert Academic Publishing, Saarbrucken.

Australian Human Resources Institute, 2009, AHRI Accredited Courses, (http://www.ahri.com.au /scripts/cgiip.exe/WService=AHRILIVE/ccms.r?PageId=10920). Accessed February 2009.

Beauchamp, T.L. and Bowie, N. (eds) 1997, Ethical theory and business, $5^{\text {th }}$ edn, Prentice-Hall, Upper Saddle River, NJ.

Bowie, N. 1990, Business Ethics as a Discipline: the Search fro Legitimacy" in R.E. Freeman Business Ethics The state of the Art, Rufon

Boyatzis, R. 1982, The competent manager, Prentice Hall, Englewood Cliffs.

Buchholz, R. 1989, Fundamental concepts and problems in business ethics, Prentice-Hall, Englewood Cliffs.

Cameron, K.S. and Whetten, D.A. 2007, Developing management skills, $7^{\text {th }}$ edn, Prentice Hall, Englewood Cliffs.

Cheetham, G. and Chivers, G. 2001, "How professionals learn in practice: an investigation of informal learning amongst people working in professions" Journal of European Industrial Training, vol. 25, no. 5 , pp. $247-292$

Cogan, M.L 1953, “Toward a definition of profession", Harvard Educational Review, vol. 23 pp. 3350

Collins, D. 2009, Essentials of Business Ethics: Creating an Organization of Integrity and Superior Performance, Wiley and Sons, Hoboken, N.J

Connock, S. and Johns, T. 1995, Ethical Leadership, Institute of Personnel and Development, London.

De George, R. 1999, Business ethics, $5^{\text {th }}$ edn, Prentice-Hall, Englewood Cliffs, N.J.

Donaldson, J. 1989, Key issues in business ethics, Academic Press, London.

Driscoll, D.N. and Hoffman, W.M. 2000, Ethics matters: how to implement values-driven management, Bentley College Center for Business Ethics, Massachusetts.

Eraut, M. R. 2000, "Non formal learning and tacit knowledge in Professional work" British Journal of Educational Psychology, vol. 70, no.1, pp. 113 - 136.

Eraut, M. 1994, Developing Professional Knowledge and Competence, The Falmer Press, London.

Ferrell, O.C, and Fraedrich, J. 1997, Business ethics: ethical decision making and cases, Houghton Mifflin, Boston

Ferrell, O.C, Fraedrich, J. and Ferrell, L. 2006, Business ethics: ethical decision making and cases, $6^{\text {th }}$ edn, Houghton Mifflin, Boston.

Flexner, A. 1910, "Medical Education in the United States and Canada: A Report to the Carnegie Foundation for the Advancement of Teaching", The Carnegie Foundation. Stanford, CA.

Francis, R. 2000, Ethics and corporate governance in Australia, Law Book Company, Sydney.

Freidson, E. 1970, The Profession of Medicine: A Study of the Sociology of Applied Knowledge, Harper and Row, New York, NY.

Frederick, R.E. (ed) 2002, A companion to business ethics, Blackwell Publishing, Oxford.

Freeman, R. (ed) 1991, Business ethics: the state of the art, Oxford University Press, New York.

Gold, J., Rodgers, H. and Smith, V. 2002, 'The future of the professions: are they up for it?' Foresight, vol. 4, no. 2, pp. 46-53

Goleman, D., Boyatzis, R.E. and McKee, A. 2004, Primal leadership: learning to lead with emotional intelligence, Harvard Business School Press, Boston.

Harrison, J. 2001, Ethics for Australian business, Prentice-Hall, Frenchs Forest.

Hellriegel, D., Jackson, S.E., and Slocum, J.W. 2007, Management: A competency-based approach, South-Western College Pub, Cincinnati, Ohio

Hoffman, W.M., Driscoll, D. and Painter-Morland, M. 2001, 'Integrating ethics', in C Moon and C Bonny (eds), Business ethics: facing up to the issues, The Economist Books, London, pp. 38-54.

Hoffman, W.M. 1995, 'A blueprint for corporate ethical development', in MW Hoffman and RE Fredrick (eds) Business ethics: readings and cases in corporate morality, $3^{\text {rd }}$ edn, McGraw Hill, New York, pp. 557-584.

Hoffman, W.M. and Fredrick, R.E. (eds) 1995, Business ethics: readings and cases in corporate morality, $3^{\text {rd }}$ edn, McGraw-Hill, New York.

Izraeli, D. and BarNir, A. 1998, "Promoting ethics through ethics Officers: A proposed profile and An Application, Journal of Business Ethics, vol 17, no. 11, pp. 1189-1196 
Koehn, D. 1994, The ground of professional ethics, Routledge, London.

Kitson, A.and Campbell, R. 1996, The Ethical Organisation: Ethical Theory and Corporate Behaviour, Macmillan Press, London.

Kouzes, J. and Posner, B. 1987, The leadership challenge, Jossey-Bass, San Francisco.

Lagan, A. 2000, Why ethics matters, Information Australia, Melbourne.

Longstaff, S. 1997, Hard cases, tough choices: exploring the ethical landscape of business, Macmillan, Sydney.

Llopis, J, Reyes-Gonzalez, M., Jose L Gasco, JL. 2007, “Corporate Governance and organisational culture: The role of ethcis officers" International Journal of Disclosure and Governance, vol. 4, no. 2 ; p. 96-106

Lusch, R.F. and O’Brien, M. 1997, "Fostering professionlism”, Marketing Research, vol. 9, no. 1, pp. 24-30.

Mangham, I.L. and Pye, A. 1991, The Doing of Management, Blackwell, London.

Matten, D., and Moon, J. 2004, 'Corporate social responsibility education in Europe'. Journal of Business Ethics, vol. 54, pp. 323- 337.

May, W. 1989, 'Vocation, career and profession', Monograph Series, The Australian Institute of Ethics and The Professions, Brisbane, vol. 1, no. 1.

McEwan, T. 2001, Managing values and beliefs in organisations, Financial Times, London.

McNamee, D. 1991, "Resolving problems in ethics and management" Managerial Auditing Journal, vol. 7, no. 2. Pp3-11

McClelland, D.C. 1973, "Testing for competence rather than for 'Intelligence", American Psychologist, vol. 28, no.1, pp.1-4.

Moon, C. and Bonny, C. (eds) 2001, Business ethics: facing up to the issues, The Economist Books, London

Oakeshott, M. 1962, Rationalism in Politics: And Other Essays, Methuen, London.

Pedler, M., Boydell, T and Burgoyne, J 2001, A Manager's guide to self-development, McGraw-Hill, London.

Petrick, J.A. and Quinn, J.F. 1997, Management ethics: integrity at work, Sage. Newbury Park.

Preston, N. 1994, Ethics for the Public Sector: Education and Training, Federation Press, Sydney

Quinn, R., Faerman, S., Thompson, M. and McGrath, M. 2007, Becoming a master manager: a competency framework, Wiley and Sons, Toronto.

Sagar, W 1995, "Characteristics of a profession" The National Public Accountant, March,

Segon, M.J. 2004, "The Australian Experience: Approaches to Integrity Systems," AAPAE Annual Conference, University of Western Sydney, Richmond, NSW October, 2004.

Segon, M.J. 2007, "Designing an Ethics system using Mintzberg's Configuration Approach" The Australian Journal of Professional and Applied Ethics, vol. 9, no. 2, pp. 66-76

Segon, M.J. and Booth, C. 2010, "Teaching Ethics: Embedding Ethics or stand-alone subjects in MBA programs" The Australian Journal of Professional and Applied Ethics, vol. 10, no. 2.

Sampford, C. 1994, 'Institutionalising public sector ethics', in N Preston (ed.), Ethics for the public sector, The Federation Press, Sydney, pp 14-34.

Solomon, R.C. and Hanson, K.R. 1983, Above the bottom line: an introduction to business ethics, Harcourt, Brace and Jovanovich. New York.

Spreitzer, G. M., McCall, M.W. and J. D. Mahoney, J.D. 1997, "Early Identification of International Executive Potential", Journal of Applied Psychology, vol.82, no. 1, pp. 6-29.

Trevino, L. K. 1986, 'Ethical Decision Making in Organizations: A Person-Situation Interactionist Model', Academy of Management Review, vol.11. no. 2, pp. 601-617.

Trevino, L.K. and Nelson, K. 1999, Managing business ethics: straight talk about how to do it right, 2n edn, Wiley and Sons, New York.

Trevino, L.K. and Nelson, K. 2006, Managing business ethics: straight talk about how to do it right, $4^{\text {th }}$ edn, Wiley and Sons, New York.

Wall, A. 1998, "Ethics and management: oil and water", in Dracopoulou, S. (Ed.), Ethics and Values in Health Care Management, Routledge, London, pp. 13-28.

Watkins, J. 1999, "Conflicting codes: Professional, ethical, and legal obligations in archaeology" Science and Engineering Ethics, vol. 5, pp 337-345 
Whetten, D.A. and Cameron, K.S. 2007Developing management skills, $7^{\text {th }}$ edn, Prentice Hall, Englewood Cliffs.

Winch, C. 2004, "What do teachers need to know about teaching? A critical examination of the occupational knowledge of teachers", British Journal of Educational Studies, Vol. 52 No. 2, pp. $180-96$.

Winstanley, D., Woodall, G., and Heery, E. 1996, "Business ethics and human resource management", Personnel Review, vol. 26, pp 5-12

Woodd, M. 1997, "Human resource specialists - guardians of ethical conduct?" Journal of European Industrial Training, vol. 21, no. 3, pp.110-116 
